\title{
Targeting cancer stem cells in cholangiocarcinoma (Review)
}

\author{
NICOLE A. McGRATH ${ }^{1}$, JIANYANG FU ${ }^{1}$, SOPHIE Z. GU $^{2}$ and CHANGQING XIE ${ }^{1}$ \\ ${ }^{1}$ Thoracic and GI Malignancies Branch, Center for Cancer Research, National Cancer Institute, National Institutes of Health, \\ Bethesda, MD 20814; ${ }^{2}$ Johns Hopkins University School of Medicine, Baltimore, MD 20215, USA
}

Received January 17, 2020; Accepted April 13, 2020

DOI: 10.3892/ijo.2020.5074

\begin{abstract}
The incidence of cholangiocarcinoma has been increasing steadily over the past 50 years, but the survival rates remained low due to the disease being highly resistant to non-surgical treatment interventions. Cancer stem cell markers are expressed in cholangiocarcinoma, suggesting that they serve a significant role in the physiology of the disease. Cancer stem cells are frequently implicated in tumor relapse and acquired resistance to a number of therapeutic strategies, including chemotherapy, radiation and immune checkpoint inhibitors. Novel targeted therapies to eradicate cancer stem cells may assist in overcoming treatment resistance in cholangiocarcinoma and reduce the rates of relapse and recurrence. Several signaling pathways have been previously documented to regulate the development and survival of cancer stem cells, including Notch, janus kinase/STAT, Hippo/yes-associated protein 1 (YAP1), Wnt and Hedgehog signaling. Although pharmacological agents have been developed to target these pathways, only modest effects were reported in clinical trials. The Hippo/YAP1 signaling pathway has come to the forefront in the field of cancer stem cell research due to its reported involvement in epithelium-mesenchymal transition, cell adhesion, organogenesis and tumorigenesis. In the present article, recent findings in terms of cancer stem cell research in cholangiocarcinoma were reviewed, where the potential therapeutic targeting of cancer stem cells in this disease was discussed.
\end{abstract}

\section{Contents}

1. Introduction

2. Defining cancer stem cells

3. Signaling pathways involved in CSC stemness and potential targets

Correspondence to: Dr Changqing Xie, Thoracic and GI Malignancies Branch, Center for Cancer Research, National Cancer Institute, National Institutes of Health, 10 Center Drive, Bethesda, MD 20814, USA

E-mail: changqing.xie@nih.gov

Key words: cancer stem cells, cholangiocarcinoma, yes-associated protein 1
4. Challenges and ongoing research targeting CSCs

5. Conclusions

\section{Introduction}

Cholangiocarcinoma (CCA) is a diverse and collective malignancy that is derived from the biliary epithelium (1). Broadly recognized risk factors for CCA include liver fluke infection, primary sclerosing cholangitis, cirrhosis, viral hepatitis, congenital anomalies of the biliary tree and hepatolithiasis (1). In addition, inflammatory bowel disease, obesity and genetic predisposition have been reported to be associated with a higher risk of developing CCA (Fig. 1) (1). Although the incidence of CCA in the United States remains relatively low, at 1.26 cases per 100,000 people as of 2015 , its prevalence has been steadily increasing over the past 50 years (2). According to analysis by race, CCA has the highest overall incidence in Asian Americans at 1.87 cases per 100,000 people, followed by Caucasian Americans at 1.23 cases per 100,000 people and lastly African Americans, which is 1.17 per 100,000 people (2). However, the mortality rate of CCA in African Americans has increased dramatically over the past decade, increasing $45 \%$ compared to $20 \%$ in Asian Americans and Caucasian Americans (3).

The current 5-year survival rate in patients with early stage CCA who undergo curative-intent surgery is $30 \%$ (4). Patients with advanced disease at diagnosis have limited treatment options and poor prognosis. In a previous surveillance program of 825 patients with CCA, regardless of treatment modality or tumor pathology, the median overall survival (OS) was found to be 7 months, whilst the 5-year survival rate was revealed to be $5.7 \%$ (5). Due to aggressive tumor growth and the presence of metastases at diagnosis, $\sim 86 \%$ of patients with CCA patients are ineligible for either curative-intent surgery or palliative resection (5). Patients ineligible for curative surgery are provided a combinatorial chemotherapy of gemcitabine and cisplatin either as adjuvant to surgery or as the first line of care. However, combination chemotherapy confers minimal survival benefit, where it modestly prolongs the median OS to 11.7 months and progression free survival to 8 months compared with a historical OS of 2.5-4.5 months with supportive care $(6,7)$. This highlights the urgent need for the development of novel effective treatment options for patients who are ineligible for surgery.

Newly developed targeted therapies have demonstrated promising clinical efficacy against chemotherapy-refractory 
CCA. In a phase II study of patients with fibroblast growth factor receptor (FGFR)-altered advanced biliary tract cancer (BTC), a selective pan-FGFR kinase inhibitor exerted impressive anti-tumor activity with a disease-control rate (DCR) of $82 \%$ (8). Additionally, in another phase I study involving patients with isocitrate dehydrogenase 1 (IDH)-positive CCA, which represents $25 \%$ of all cases of CCA, the IDH1 inhibitor ivosidenib exhibited a well-tolerated safety profile with an overall response rate (ORR) of 5\% and an OS of 13.8 months (9). However, these aforementioned promising targeted therapies were only viable for a relatively small percentage of patients with CCA with the specific IDH1 and FGFR mutations aforementioned (9).

Within the last decade, immunotherapy has become a major pillar of cancer therapy. Immune checkpoint inhibitors (ICIs) act by targeting dysregulated immune checkpoints, including programmed death protein 1 (PD-1) and programmed death ligand (PD-L1), which affect anti-tumor immunity in several types of cancers (10). Accumulating evidence have demonstrated encouraging results in applications with ICIs alone for treating hepatocellular carcinoma (HCC), with response rates reaching $\sim 15-20 \%(11,12)$. However, ICIs have demonstrated minimal efficacy for the treatment of CCA $(13,14)$. In a recent study of advanced BTCs that were treated with a combination of an ICI and microwave ablation, the ORR was found to be $12.5 \%$ (15). Novel therapeutic strategies to combat CCA progression are therefore urgently sought. One emerging target in this research field is cancer stem cells (CSCs), also referred to as tumor-initiating or -propagating cells.

\section{Defining cancer stem cells}

There is increasing consensus supporting the existence of a distinct cellular hierarchy within a tumor, where CSCs are unique originators of all tumor cells and are responsible for tumor growth (16-18). CSCs have been implicated in CCA along with a variety of other solid tumors, including breast, brain, colorectal (CRC), pancreatic, liver, melanoma, ovarian and prostate cancer (Tables I and II). It is hypothesized that CSCs survive following the initial stages of cancer therapy and thereby facilitate relapse and metastasis, where they are responsible for acquired resistance to conventional cancer treatment regimens, including radiation therapy and the more recently discovered immunotherapy (18-20). CSCs may be able to evade the immune system by altering their immunogenicity, enabling the avoidance of rejection mediated by the immune system in vivo (21). CSCs are defined by their enriched capacity for self-renewal and differentiation into explicit malignant progenies. Tumors with CSC-enriched phenotypes are considerably more plastic than originally anticipated, which are in turn heavily influenced by the tumor microenvironment, rendering the design of therapeutic methodology against them difficult (22). In addition, although previous reports suggested a frequency of $<1$ CSC per 1,000 cancer cells, the proportion of CSCs with tumorigenic capacity could be much higher $(23,24)$. CSCs can be uniquely characterized by their cell-surface markers, where several markers have been used to identify CSCs in various types of cancers such as CCA (Tables I and II).

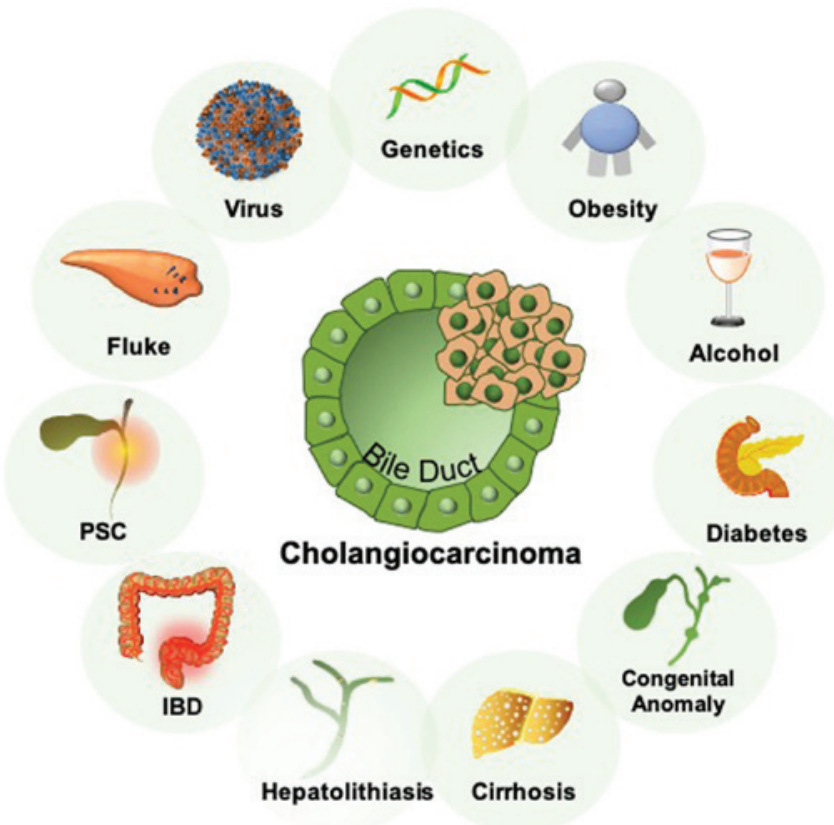

Figure 1. Established risk factors of cholangiocarcinoma. PSC, primary sclerosing cholangitis; IBD, inflammatory bowel disease.

CD133.CD133, also known as prominin-1, is a pentaspan transmembrane glycoprotein that appears to be an epithelial marker in tissues in addition to being a CSC marker (24). Although the precise function of $\mathrm{CD} 133$ remains unclear, considerable evidence exists for the increased capabilities for tumor initiation in $\mathrm{CD}_{133^{+}}$cell cultures and tumor xenografts (24-28). The presence of CD133 along with other suspected CSC markers has also been associated with poorer overall survival in patients with CCA (29). In a previous study of 29 patients with intrahepatic CCA who had undergone major hepatectomies, only $8 \%$ of $\mathrm{CD} 133^{+}$patients remained alive 5 years following surgery, compared with $57 \%$ among CD133 patients $(\mathrm{P}=0.02)$ (29). Consistent with this notion, $\mathrm{CD} 133^{+}$liver cancer cell lines appear to exhibit significantly higher resistance to autophagy as a result of IFN- $\gamma$ treatment compared with the corresponding CD133 cell lines in vitro (28). This finding has been corroborated in vivo, where CD133- tumors shrank in cirrhosis-associated HCC cells in mice treated with IFN- $\gamma$. By contrast, tumors of the $\mathrm{CD} 133^{+}$phenotype were resistant and instead became further enriched with $\mathrm{CD}_{133^{+}}$expression (28).

CD44 and CD24. CD44 is a cell-surface glycoprotein that is involved in cell-cell adhesion and migration $(30,31)$. Functionally, it is involved in leukocyte homing and activation, wound healing and cell migration $(30,31)$. CD44s, the conventional isoform of CD44, is expressed in normal epithelial cells and serves as an adhesion molecule in the extracellular matrix $(30,31)$. In some carcinomas of epithelial origin, variant isoforms of CD44 have been implicated in tumor metastasis and invasion (32). Previous studies have suggested CD44 and its variant isoforms to be responsible for cellular stemness characteristics, associated with resistance to reactive oxygen species (ROS) in CSCs and implicated in the progression of malignancies in gastrointestinal system $(30,31)$. However, it should be noted that the clinical relevance of different CD44 isoforms are 
Table I. Cancer stem cell markers from various solid tumors.

\begin{tabular}{|c|c|c|c|}
\hline Marker & Type of cancer & In vitro assay & In vivo study (Xenograft) \\
\hline \multirow[t]{10}{*}{ CD133 } & Brain & Sphere formation (94) & NOD/SCID mice (106), nude mice (94) \\
\hline & Breast & Colony formation (95) & NOD/SCID mice (95) \\
\hline & Colon & Clonosphere formation $(96,97)$ & NOD/SCID mice $(96,107)$ \\
\hline & Kidney & Colony formation (98) & SCID mice (98) \\
\hline & Hepatic & Colony formation $(97,99)$ & NOD/SCID (97), SCID mice (99) \\
\hline & Lung & Sphere formation (100) & SCID mice $(100)$ \\
\hline & Melanoma & Colony formation (101) & N/A \\
\hline & Ovarian & Sphere formation $(102,103)$ & NSG mice (102), NOG mice (103) \\
\hline & Pancreatic & Colony formation (104) & N/A \\
\hline & Prostate & Colony formation (105) & Nude mice (108) \\
\hline \multirow[t]{5}{*}{ CD90 } & Brain & Sphere formation (109) & NOD/SCID mice (103) \\
\hline & Hepatic & Sphere formation (110) & NOD/SCID mice (110) \\
\hline & Lung & Colony and sphere formation (111) & NOD/SCID mice (111) \\
\hline & Ovarian & Colony formation (112) & NOD/SCID mice (112) \\
\hline & Stomach & Sphere formation (113) & ALB/c nude mice (113) \\
\hline \multirow[t]{9}{*}{ ALDH1 } & Brain & Colony formation (114) & Nude mice (114) \\
\hline & Breast & IHC staining (115) & BALB/c mice (120) \\
\hline & Colon & Colony (116) and sphere formation (117) & Nude mice (117) \\
\hline & Hepatic & Colony formation (99) & SCID mice (99) \\
\hline & Lung & Colony formation (118) & N/A \\
\hline & Melanoma & $\mathrm{N} / \mathrm{A}$ & NOD/SCID mice (121) \\
\hline & Ovarian & Sphere formation $(102,103)$ & $\mathrm{NSG}^{\mathrm{TM}}$ mice $(102), \mathrm{NOG}^{\circledR}$ mice $(103)$ \\
\hline & Pancreatic & N/A & NMRI nu/nu mice (122) \\
\hline & Prostate & Sphere formation (119) & NOD/SCID mice (119) \\
\hline \multirow[t]{10}{*}{ CD44 } & Brain & Colony (123) and sphere formation (124) & CD44 KO mice (123), nude mice (124) \\
\hline & Breast & IHC staining (115) & N/A \\
\hline & Colon & Colony formation (125) & NOD/SCID (131), BALB/c mice (125) \\
\hline & Kidney & IHC staining (126) & $\mathrm{N} / \mathrm{A}$ \\
\hline & Hepatic & Colony formation (127) & NOD/SCID mice (127) \\
\hline & Lung & Colony and sphere formation (111) & NOD/SCID (111), BALB/c mice (132) \\
\hline & Ovarian & Sphere formation (128) & NOD/SCID mice (128) \\
\hline & Pancreatic & $\mathrm{N} / \mathrm{A}$ & NOD/SCID mice (133) \\
\hline & Prostate & Colony (105) and sphere formation (129) & NOD/SCID mice (129) \\
\hline & Stomach & IHC staining (130) & SCID mice (134) \\
\hline \multirow[t]{5}{*}{ EpCAM } & Breast & Sphere formation (135) & NOD/SCID mice (135) \\
\hline & Colon & Colony formation (136) & $\mathrm{N} / \mathrm{A}$ \\
\hline & Hepatic & Sphere formation (110) & NOD/SCID mice (110) \\
\hline & Ovarian & Sphere formation (128) & N/A \\
\hline & Pancreatic & $\mathrm{N} / \mathrm{A}$ & NOD/SCID mice (133) \\
\hline \multirow[t]{5}{*}{$\mathrm{CD} 24$} & Breast & IHC staining (115) & BALB/c mice (120) \\
\hline & Colon & Colony formation (137) & NOD/SCID mice (137) \\
\hline & Hepatic & Colony formation (138) & Nude mice, SCID mice (138) \\
\hline & Ovarian & Sphere formation (128) & NOD/SCID mice (128) \\
\hline & Pancreatic & $\mathrm{N} / \mathrm{A}$ & NOD/SCID mice (133) \\
\hline \multirow[t]{3}{*}{$\mathrm{SOX} 2$} & Brain & Colony formation (139) & NOD/SCID mice (139) \\
\hline & Breast & Colony formation (140) & Nude mice, BALB/c mice (140) \\
\hline & Lung & Colony formation (141) & Nude mice (141) \\
\hline \multirow[t]{4}{*}{ NANOG } & Brain & Sphere formation (142) & Nude mice (142) \\
\hline & Hepatic & Colony and sphere formation (138) & NOD/SCID, BALB/c mice (138) \\
\hline & Prostate & Sphere formation (143) & NOD/SCID mice (143) \\
\hline & Testis & IHC staining (144) & $\mathrm{N} / \mathrm{A}$ \\
\hline
\end{tabular}

NOD, non-obsese diabetic; SCID, severe combined immunodeficient; KO, knockout; ALDH1, aldehyde dehydrogenase 1; EpCAM, epithelial cell adhesion molecule; SOX2, SRY-box transcription factor 2. 
Table II. Cancer stem cell markers in cholangiocarcinoma.

\begin{tabular}{lll}
\hline Marker & \multicolumn{1}{c}{ In vitro assay } & \multicolumn{1}{c}{ In vivo study (xenograft) } \\
\hline CD133 & Sphere formation (24) & BALB/c, NOD/SCID mice (24) \\
CD90 & Sphere formation (24) & BALB/c mice, NOD/SCID mice (24) \\
ALDH1 & Colony formation (46) & NOD/SCID mice (46) \\
CD44 & Sphere formation (36) & NOD/SCID mice (45) \\
EpCAM & Sphere formation (24) & NOD/SCID mice (45) \\
CD24 & Sphere formation (36) & NOD/SCID mice (45) \\
SOX2 & Immunohistochemical human samples (50) & NOD/SCID mice (139)
\end{tabular}

ALDH1, aldehyde dehydrogenase 1; EpCAM, epithelial cell adhesion molecule; SOX2, SRY-box transcription factor 2; NOD, non-obsese diabetic; SCID, severe combined immunodeficient.

highly dependent of the type of cancer. For example, CD44v6 appeared to be unrelated to the CCA progression, whilst CD44v9 appears to be clinically relevant to the disease (32-34). In a previous immunohistochemistry analysis of CCA tumors, CD44v9 was found to associate with the expression of inflammatory markers cyclooxygenase-2 (COX2) and S100 Calcium Binding Protein P, where CD44v9 expression was found to be higher in CCA associated with liver fluke infection (32).

There have been disparities in the findings regarding the use of CD2 4 as a CSC marker. The CD $44^{\text {high }} / \mathrm{CD} 24^{\text {low }}$ cell phenotype has been repeatedly utilized as a signature of CSCs in breast tumors, where they were demonstrated to be chemoresistant following chemotherapy (35). Similar findings were also documented in a previous in vitro study of CCA (36). In CCA cell lines, a shift from CD $44^{\text {high }} / \mathrm{CD} 24^{\text {high }}$ to $\mathrm{CD} 44^{\text {high }} / \mathrm{CD} 24^{\text {low }}$ was observed in cells resistant to epidermal growth factor receptor inhibition (36). By contrast, pharmacological depletion of ROS scavengers resulted in increased sensitivity to radiotherapy and depleted clonogenicity in the $\mathrm{CD} 24^{+} \mathrm{CD} 90^{+}$-enriched cell population, suggesting that the $\mathrm{CD} 24^{+} \mathrm{CD} 90^{+}$combination may be responsible for mediating resistance to radiation in CSCs (37). In patients with CCA who received chemotherapy and radiation, CD24 expression was previously found to be associated with a lower median survival time (38). To verify these findings, further research on the individual role of CD24 in CSCs and cancer progression is required.

Epithelial cell adhesion molecule (EpCAM). EpCAM is a downstream signaling target of the Wnt pathway $(39,40)$. Wnt signaling was previously demonstrated to be simultaneously decreased in colon cancer cells following EpCAM knockdown (39). Furthermore, it was previously found in HCC that EpCAM expression is dependent on the nuclear accumulation of $\beta$-catenin (40). EpCAM has been applied as a prognostic marker for a number of epithelial cancers, including HCC and CCA (41-44). In accordance with in vitro studies of the individual tumorigenic potential of CSC markers, CD $44^{+} \mathrm{CD} 24^{+} \mathrm{EpCAM}^{+}$ cells isolated from extrahepatic CCA xenografts in immunocompromised mouse exhibited higher tumorigenicity compared with those of the CD44-CD24-EpCAM- phenotype (45).

Aldehyde dehydrogenases (ALDH). ALDH belong to a family of intracellular enzymes that are involved in cellular detoxification, differentiation, and drug resistance $(46,47)$. Although ALDH1 has been most commonly applied as a CSC marker in breast cancer, it has also been previously implicated in CCA and HCC $(46,47)$, where the expression level of ALDH1 was found to be correlated with poor prognosis in patients with CCA $(46,47)$. In addition, ALDH1 expression has been demonstrated to potentiate mesenchymal properties in the CCA cell line TFK-1 (46). However, conflicting evidence exists with regards to the role of ALDH1 in CRC compared with that in CCA. In CRC, it was hypothesized that the expression of extracellular, rather than intracellular CSC markers, may serve as superior indicators of tumor stemness $(23,24)$.

SRY-box transcription factor (SOX)2, NANOG, and octamer-binding transcription factor 4 (OCT4). SOX2, NANOG and OCT4 are all transcription factors essential for the maintenance of stemness in embryonic stem cells and have been previously used as markers for CSCs (48). They directly communicate with each other during embryonic development, where they suppress differentiation into progenitor cells (48). NANOG, OCT4, and SOX2 expression have all been previously revealed to be associated with poor prognosis in rectal cancer, glioma and CCA (49). In rectal cancer, expression of $\geq 2$ in comparison to $\leq 1$ of these markers was found to associate significantly with poorer OS. In particular, OCT4 was also demonstrated to be independently associated with poor tumor differentiation, higher $\mathrm{N}$ stage and larger tumor size in rectal cancer (48). Likewise in CCA, co-expression of OCT4 and Nanog was found to be associated with the most inferior of the clinical outcomes (49). Elevated SOX2 expression has also been previously associated with poorly differentiated tumors, metastasis and insignificantly, vascular invasion and tumor stage in CCA (50). Patients with CCA in which SOX2 was overexpressed, exhibited significantly lower OS with no difference in DFS (50).

Overall, based on the data available on CSC markers, it is important to characterize CSCs in tumors by using multiple markers instead of reliance on any single marker.

\section{Signaling pathways involved in CSC stemness and potential targets}

In addition to the expression of cell surface molecules that are typically associated with stem cells, CSCs exhibit classical 


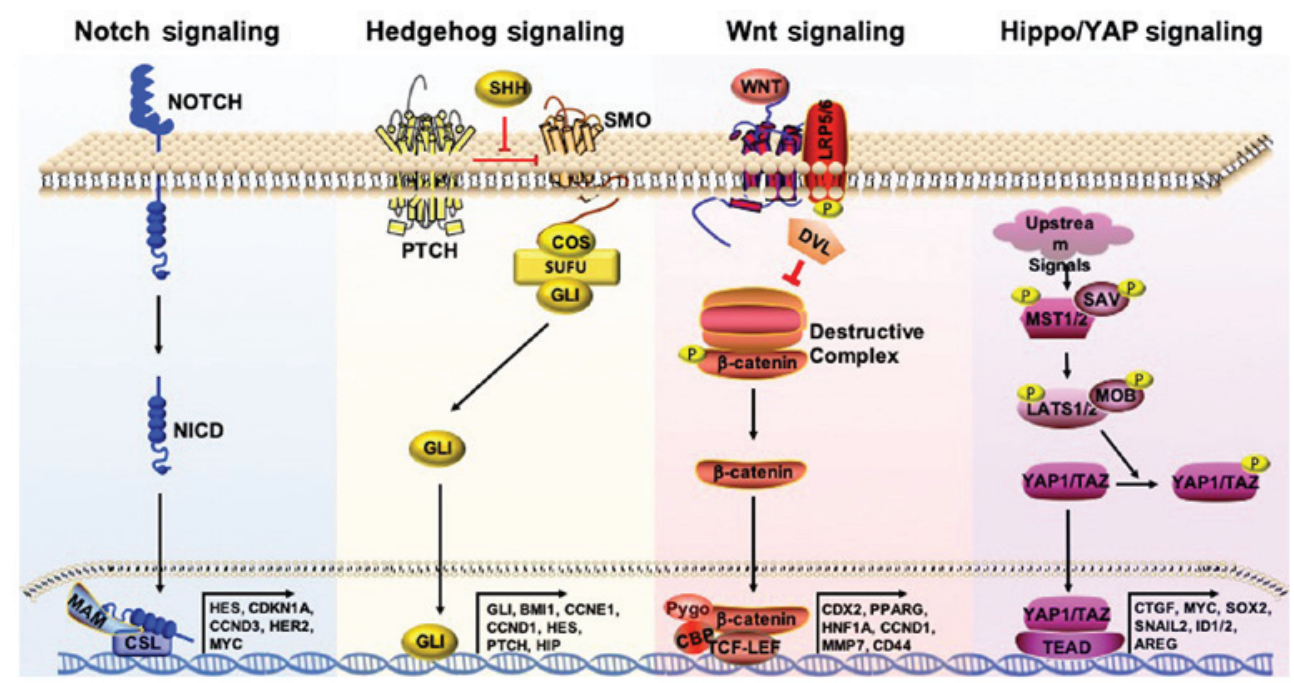

Figure 2. Pathways involved in CSC Development. Hippo/YAP1, Notch, Hedgehog, and Wnt signaling are all pathways implicated in the development of stemness features, including EMT, cell migration and proliferation, and tumorigenesis. The regulation of their target genes plays a vital role in CSC development. YAP1, yes-associated protein 1; EMT, epithelial-to-mesenchymal transition; CSC, cancer stem cells; MAM, mastermind; CSL, CBF-1, suppressor of hairless, lag-1; HES, hairy and enhancer of split; CDKN1A, cyclin dependent kinase inhibitor 1A; CCND3, cyclin D3; COS, costal; HER2, human epidermal growth factor receptor 2; PTCH, patched; SHH, sonic hedgehog; SMO, smoothened; SUFU, suppressor of fused homolog; CCND1, cyclin D1; HIP, hedgehog-interacting protein; LRP5/6, Low-density lipoprotein receptor-related protein 5/6; DVL, disheveled; Pygo, pygopus; TCF-LEF, T-cell factor/lymphoid enhancer factor; CBP, CREB binding protein; CDX2, caudal type homeobox 2; PPARG, Peroxisome proliferator activated receptor- $\gamma$; HNF1A, hepatic nuclear factor 1 $\alpha$; MMP7, matrix metalloproteinase 1; MST1/2, macrophage stimulating 1; SAV, salvador family WW domain containing protein 1; MOB, phocein; LATS1/2, large tumor suppressor kinase 1/2; TAZ, tafazzin; TEAD, transcriptional enhancer factor; CTGF, connective tissue growth factor; SOX2, SRY-box transcription factor 2; ID1/2, inhibitor of differentiation 1/2, AREG, amphiregulin.

features of stem cells such as the ability to differentiate into explicit progenies (51). Signal transduction pathways that are highly active in embryonic and adult stem cells, including Notch, Hedgehog and Wnt, are also highly active in CSCs (Fig. 2) (19). In this section, the various signaling pathways involved in CSC maintenance and research that are focused on targeting these pathways will be outlined.

Hippo/Yes-associated Protein (YAP1). The Hippo/YAP1 is a signaling pathway that is highly conserved among the majority of mammalian species. It has recently garnered significant attention due to its reported role in regulating CSCs (52). Core kinases involved in this pathway include macrophage stimulating (MST) 1/2 and large tumor suppressor kinase (LATS) $1 / 2$, which are under regulation by scaffolding proteins Salvador family WW domain containing protein 1 and phocein (MOB), respectively (Fig. 2). Activation of MST and LATS leads to the phosphorylation and subsequent inactivation of YAP1. This inhibits YAP1 from entering the nucleus, where it would normally bind to the transcriptional enhancer factor (TEAD) and SMAD families of transcription factors, leading to the transcription of a number of oncogenic genes, including SOX9, amphiregulin, MYC and Gli1 (53-55).

YAP1 overexpression is associated with tumorigenesis, epithelial-to-mesenchymal transition (EMT), in addition to tumor angiogenesis and invasion, physiological processes that have been previously demonstrated to lead to unfavorable prognoses in malignancies, including CCA, HCC, lung, brain, ovarian, breast, bladder and colon cancer (56-60). YAP1 expression was found to be an independent prognostic factor in both human and animal studies of CCA $(57,59)$. Previous studies have demonstrated that liver-specific MOB1a/1b double knockout (61) and MST1/2 conditional knockout mice (62) exhibited phenotypically mixed HCC/CCA inducible tumors. These findings suggest that the Hippo/YAP1 signaling pathway is critical for liver tumorigenesis. Intriguingly, the introduction of activated YAP1 and myristoylated AKT in the biliary tract, coupled with biliary ligation, triggered CCA formation in an IL-6-dependent manner within 6-8 weeks in $>70 \%$ of the mice tested (63). This was performed through the ectopic expression of the constitutively active AKT and YAP1 using the Sleeping Beauty transposon transfection system. This study not only highlighted the potential role of inflammatory cytokines on CCA oncogenesis but also suggests YAP1 to be an important driver of CCA tumorigenesis.

A number of studies have indicated that the Hippo/YAP1 pathway serves an integral role in the maintenance of CSCs. YAP1 overexpression directly upregulates SOX9 in esophageal cancer, which in turn endows cancer cells with stem-like properties $(64,65)$. In addition, YAP1 can induce the expression of the embryonic stem cell transcription factor SOX2 and co-operate with the pro-inflammatory COX2 pathway to expand the population of CSCs in urothelial cancer (66). Immunohistochemistry analysis of COX2 and YAP1 expression in bladder cancer samples previously demonstrated that these two proteins can mediate resistance to treatment, whilst the in vitro inhibition of these proteins significantly reduced tumor growth (66). Additionally, the expression of YAP1 was found to be upregulated in CSCs in non-small cell lung cancer (NSCLC) cell lines, which was believed to contribute to their capacity for self-renewal forming angiogenic tubules (67). This previous study also showed that knocking down YAP1 expression can significantly reduce the spheroid forming and proliferative capacity of NSCLC (67). Interestingly, the effects of YAP1 were revealed to be mediated through induction of SOX2, which then directly interacts with OCT4, in a manner 


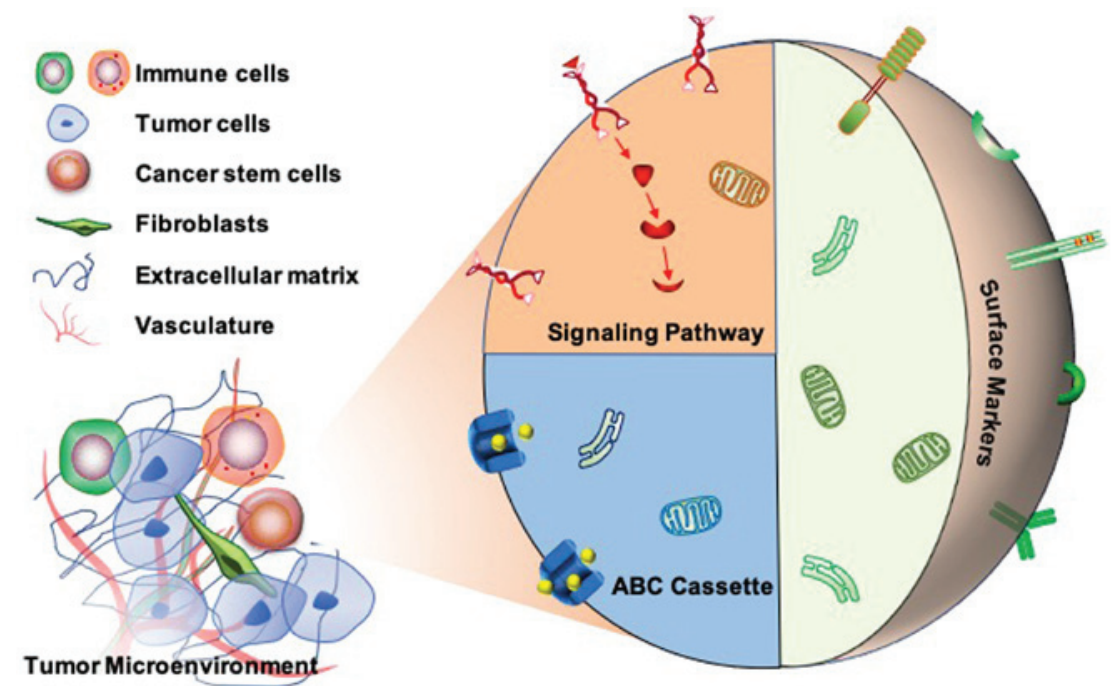

Figure 3. Strategies to target cancer stem cells. Many strategies aimed at eradicating CSCs have been developed and the main areas have been summarized, including targeting cell surface markers, signaling pathways and drug efflux transporters. ABC, ATP-binding cassette.

that was independent of TEAD2 (67). It was reported previously that long noncoding RNAs are highly expressed in CSCs of $\mathrm{HCC}$, which are required for the self-maintenance of liver CSCs (68). Among those, lncBRM initiates YAP1 signaling activation to drive the self-renewal of liver CSCs (68). In conclusion, these findings suggest that YAP1 likely serve a pivotal role in the maintenance of stemness in CSCs.

Until recently, targeting the Hippo/YAP1 signaling pathway has proved challenging due to its complexity and substantial crosstalk with other pathways. Verteporfin, a photodynamic drug that was traditionally used for treating macular degeneration, has recently emerged as a YAP/tafazzin (TAZ) inhibitor, where it has demonstrated promising preclinical results in cancers such as CCA (57). The combination of verteporfin and rapamycin was previously found to inhibit intrahepatic CCA cell proliferation and tumor growth (57), where verteporfin activated mTOR whilst inhibiting STAT3 phosphorylation in CCA (57). However, to the best of our knowledge, no clinical studies on the effects of verteporfin on CCA or CSCs in other cancers have been performed.

In a recent study, LEE011 was found to inhibit cyclin-dependent kinase 6 (CDK6), whilst CA3 inhibited YAP1, using both in vivo and in vitro models of esophageal cancer (69). YAP1 and CDK6 expression were also revealed to associate positively with each other and with resistance to radiation (69). Combined treatment using both CA3 and LEE011 reduced tumor volume to a greater degree compared with either treatment alone. These findings suggest that YAP1 may synergize with CDK6 to induce cell proliferation and resistance to chemotherapy in cancer (69). However, to date, no clinical studies have been conducted using the novel Hippo/YAP1 inhibitors. Further research devoted to the effects of Hippo/YAP1 on CSC formation may prove to be beneficial for the treatment of refractory cancers such as CCA.

Sonic Hedgehog. Hedgehog $(\mathrm{Hh})$ protein activation by Patched triggers a signaling cascade that regulates proliferation, metastasis and invasion in cancer cells (70). In addition, it has also been implicated in the stemness maintenance of CSCs (19). A previous study has found that hypoxia induces Hh activation in CCA, which was demonstrated to be positively associated with the induction of EMT, and upregulation of the stemness markers, including NANOG, Oct4, SOX2, CD133 in vitro (27).

Application of the Hh inhibitor Saridegib, in combination with gemcitabine, did not exert notable therapeutic effects on metastatic pancreatic cancer in phase II trials (71). Additionally, whilst there were promising preclinical and phase I data for this trial, control patients exhibited longer OS compared with those treated with the $\mathrm{Hh}$ inhibitor $(71,72)$. Glasdegib and Vismodegib are currently the two FDA-approved Hh signaling inhibitors that have been extensively studied in relation to malignancies such as acute myeloid leukemia (73). However, since research on their effects in other cancers have been mostly discontinued, they have not been studied clinically in CCA.

Notch. The Notch signaling pathway has been extensively studied in cancer, where it was suggested to be important for the regulation of cell survival and apoptosis (74). Notch is cleaved sequentially by tumor necrosis factor- $\alpha$ converting enzyme (TACE) and $\gamma$-secretase, resulting in the release of the intracellular domain of Notch (NICD). NICD then translocates into the nucleus where it mediates the transcription of target genes, including hairy and enhancer of split- $1, \mathrm{NF}-\kappa \mathrm{B}$, cyclin D1 and c-myc (75). The Notch1 receptor and the Notch ligand Jagged 1 was found to be overexpressed in four human CCA cell lines (76). In addition, overexpression of NICD in mouse livers has been previously found to induce cystic CCA tumor development (77). These observations suggest that Notch can serve as a potential target for controlling CSCs (78).

$\gamma$-secretase inhibitors are among the largest class of Notch inhibitors, with $>12$ different clinical trials having previously applied this class of drug (19). However, none have progressed to phase III trials due to inefficacy or intolerance and therefore development of drugs of this class has been discontinued. Antibodies specifically targeting Notch 1-3 have also been developed, but like $\gamma$-secretase inhibitors, research on this class of drug has been repeatedly discontinued (19). By 
Table III. Active clinical trials targeting CSCs in solid tumors.

\begin{tabular}{|c|c|c|c|}
\hline Trial identifier & Type of solid tumor & Experimental arm & Phase \\
\hline NCT03949283 & $\begin{array}{l}\text { Recurrent ovarian carcinoma, } \\
\text { platinum-resistant ovarian cancer }\end{array}$ & Chemo ID assay & III \\
\hline NCT02232633 & $\mathrm{HCC}, \mathrm{CCA}$ & BBI503 & II \\
\hline NCT03632798 & Recurrent ovarian cancer & Chemo ID assay & III \\
\hline NCT03632135 & Recurrent glioblastoma & Chemo ID assay & III \\
\hline NCT02642094 & Breast cancer & Rapamycin & II \\
\hline NCT03548571 & Glioblastoma & Dendritic cell immunization, adjuvant temozolomide & II, III \\
\hline NCT03298763 & Lung adenocarcinoma & MSCTRIAL & I, II \\
\hline NCT02859415 & Thoracic cancer & Mithramycin & I, II \\
\hline NCT02279719 & $\mathrm{HCC}$ & BBI608, BBI503, in combination with sorafenib & I, II \\
\hline NCT03186937 & Triple negative breast cancer & Hominex-2 & II \\
\hline NCT02370238 & Metastatic breast cancer & Paclitaxel, reparixin & II \\
\hline NCT03030287 & Ovarian, peritoneal, fallopian cancer & OMP-305B83, paclitaxel & I \\
\hline NCT03927573 & NSCLC, breast, pancreatic, urogenital & GEM3PSCA & I \\
\hline NCT03572283 & Pancreatic cancer & Bethanechol & I \\
\hline NCT02753127 & Colorectal & Napabucasin + FOLFIRI & III \\
\hline NCT02157051 & Breast cancer & $\begin{array}{l}\mathrm{CD} 105 / \mathrm{Yb}-1 / \mathrm{SOX} 2 / \mathrm{CDH} 3 / \mathrm{MDM} 2 \text {-polyepitope } \\
\text { plasmid DNA vaccine }\end{array}$ & I \\
\hline NCT03466450 & Glioblastoma & Glasdegib and temozolomide & I, II \\
\hline NCT03816163 & Pancreatic cancer & Zolbetuximab + nab-paclitaxel + gemcitabine & II \\
\hline NCT02432326 & Solid tumors & BBI608, BBI503 & I \\
\hline NCT02483247 & Solid tumors & $\begin{array}{l}\text { BBI503 in combination: capecitabine doxorubicin } \\
\text { nivolumab pembrolizumab paclitaxel or sunitinib }\end{array}$ & I, II \\
\hline NCT02467361 & Metastatic cancer & $\begin{array}{l}\text { BBI608 in combination: pilimumab, } \\
\text { nivolumab, or pembrolizumab }\end{array}$ & $\mathrm{I}, \mathrm{II}$ \\
\hline NCT02776917 & Breast cancer & Cirmtuzumab + paclitaxel & I \\
\hline NCT03851614 & $\begin{array}{l}\text { Mismatch repair proficient CRC, } \\
\text { PAC, leiomyosarcoma }\end{array}$ & $\begin{array}{l}\text { Durvalumab in combination with } \\
\text { olaparib or cediranib }\end{array}$ & II \\
\hline NCT02231723 & PDAC & BBI608 in combination with four standard chemotherapies & I \\
\hline NCT02024607 & $\begin{array}{l}\text { CRC, HCC, PDAC, CCA, } \\
\text { EAC or gastric cancer }\end{array}$ & BBI608 in combination with 7 standard chemotherapies & $\mathrm{I}, \mathrm{II}$ \\
\hline NCT01781455 & Solid tumors & BBI503 & I, II \\
\hline NCT02903771 & Ovarian, peritoneal, fallopian cancer & Cantrixil & I \\
\hline NCT01372579 & Breast cancer & Eribulin mesylate, carboplatin & II \\
\hline
\end{tabular}

NSCLC, non-small cell lung cancer; CRC, colorectal cancer; HCC, hepatocellular carcinoma; PDAC, pancreatic ductal adenocarcinoma; PAC, pancreatic adenocarcinoma; CCA, cholangiocarcinoma; EAC, esophageal adenocarcinoma.

contrast, the anti-delta like canonical notch ligand 4 antibody, Demcizumab, has progressed to randomized phase II trials in lung and pancreatic cancer after exhibiting a manageable safety profile and an ORR of 51\% in phase I NSCLC trials (19). No data on its use in CCA are currently available.

$W n t / \beta$-catenin. The Wnt/ $\beta$-catenin signaling pathway is one of widely studied pathways in cancer research. Notably, $\mathrm{CRC}$ is initiated by mutations in genes such as adenomatous polyposis coli (APC), which activates the Wnt/ $\beta$-catenin pathway (79). In the canonical $\mathrm{Wnt} / \beta$-catenin pathway, Wnt ligands bind to Frizzled and low-density lipoprotein receptor-related protein receptor complexes, initiating the recruitment of scaffold proteins and disruption of the $\beta$-catenin destruction complex. Mutations in this complex, including that of APC, can lead to $\beta$-catenin accumulation in the cytosol. The accumulated $\beta$-catenin then translocates into the nucleus where it associates with the TCF family of transcription factors and a number of co-activators, including TAZ, to initiate the transcription of target genes. It has been previously reported that the canonical Wnt $/ \beta$-catenin signaling pathway is activated in human CCA, where the inhibition of Wnt/ $\beta$-catenin signaling reduced proliferation whilst inducing apoptosis in vivo (80). However, it remains unclear how the Wnt signaling pathway serves a role on the stemness of CSCs. The canonical Wnt/ $\beta$-catenin pathway has been previously reported to be directly regulated by TAZ, an effector of the Hippo/YAP1 pathway (81). 
LY2090314 is a glycogen synthase kinase 3 inhibitor, which induces the accumulation of $\beta$-catenin (Fig. 2). It has been shown that LY2090314 treatment in conjunction with nab-paclitaxel in a preclinical model of pancreatic cancer prolonged mice survival (82). However, regimens consisting of LY2090314 in combination with pemetrexed and carboplatin, demonstrated suboptimal safety profiles and minimal clinical efficacy in patients with advanced pancreatic cancer in a previous phase I clinical trial (83). BBI503 is a novel stemness kinase inhibitor that inhibits Nanog and serine/threonine kinase 17a, which induces $\beta$-catenin accumulation by stabilizing the $\beta$-catenin destruction complex (Fig. 2). Phase I data on BBI503 indicated prolonged OS and disease control in patients with CRC tumors with positive Nanog expression $(84,85)$. Phase II trials in both patients with HCC and CCA in addition to those with other types of solid tumors are under way $(84,85)$.

$J A K / S T A T$. STATs are a family of cytoplasmic transcription factors that serve key roles in maintaining cancer stemness. They exert significant influence on cellular survival, proliferation, differentiation and apoptosis by mediating responses to cytokine, hormone and growth factor signaling. Genetic variations in the JAK/STAT signaling pathway appear to be associated with CRC (86). Notably, abnormalities in STAT3 have been revealed to be involved in the oncogenesis of a number of cancers, where it was demonstrated that STAT3 and both JAK1 and JAK2 are involved in CRC cell growth, survival, invasion and migration through the regulation of target gene expression, including Bcl-2, E-cadherin, vascular endothelial growth factor and matrix metalloproteinases (86).

Napabucasin (BBI608), a drug that targets the transcription factor STAT3 to reduce stemness characteristics, has reached phase III trials (87). In phase II trials in CRC, napabucasin, in combination with standard chemotherapy, exhibited an impressive DCR of $93 \%$ and an ORR of $33 \%$ (88). Napabucasin has also been studied preclinically in CCA, where treatment with this drug resulted in general cytotoxicity and inhibited cancer stemness (89). In addition, napabucasin has been shown to inhibit colony formation and significantly downregulate the expression of several stemness-related genes, including CSC markers ALDH1 and CD133 in CCA cells (89).

\section{Challenges and ongoing research targeting CSCs}

To the best of our knowledge, no single agent is currently available that can effectively target CSCs. One of the reasons is the substantial crosstalk among the pathways aforementioned. For example, phosphorylated YAP in the cytoplasm can associate with $\beta$-catenin to promote its degradation (90). Furthermore, nuclear $\beta$-catenin can associate with TAZ and SMAD to induce transcription of Wnt target genes. Recently, it was discovered that the loss of MST1/2 in hepatocytes, a core kinase of the Hippo pathway, led to the activation of Notch signaling (91). This resulted in severe liver enlargement and HCC formation due to a positive feedback loop with YAP/TAZ (91). Knockdown of $\beta$-catenin expression in the livers of MST1/2-null mice was found to increase tumorigenesis, revealing an inhibitory role of Wnt in relation to YAP (91). Additionally, Hh can interact with both the Wnt and Notch pathways, where increased Hh signaling can upregulate the expression of the Notch ligand and Jagged 2 in neuronal stem cells, thereby maintaining stemness (92). It is possible that this phenomena is conserved in cancer. Secreted frizzled protein 1 is an integral protein upstream in the Wnt signaling cascade that was previously identified as a target of Hh signaling through the actions of Gli1/2 (93). All aforementioned crosstalk between the signaling pathways increase the complexity and challenge of targeting CSCs using a single agent.

Given the role of CSCs in cancer relapse and metastasis, there is an urgent need for the development of novel therapies that target CSCs to effectively eradicate cancer (Fig. 3). Even with the knowledge of the pathways involved in the development and maintenance of CSCs, designing pharmacological agents for targeting these pathways has proven to be exceedingly difficult. Although there are only a small number of clinical drugs currently available that are hypothesized to target CSCs exclusively, a number of clinical trials targeting CSCs in different types of cancer, including CCA, are currently ongoing (Table III).

\section{Conclusions}

CSCs have the ability to hide from the immune system and resist therapies designed to kill cancer cells. YAP1 is a downstream effector of the Hippo/YAP1 pathway, where the dysregulation of this pathway leads to oncogenesis and the enhancement of cell stemness. A number of drugs have attempted to targeted cancer stemness with modest effects in clinical trials. The Hippo/YAP1 pathway has become an attractive target for novel CSC inhibition. Although novel therapeutic agents targeting CSCs have demonstrated promise in preclinical research, none have demonstrated satisfactory outcomes in clinical settings. The complexity of crosstalk between signaling pathways therefore warrants further research. Given the resistance of CCA to non-surgical treatment, patients with CCA may benefit substantially from research on this topic.

\section{Acknowledgements}

Not applicable.

\section{Funding}

The present study is supported by Physician-Scientist Early Investigator Program at CCR of NIH/NCI to CX.

\section{Availability of data and materials}

The datasets generated during the current study are not publicly available because they consist of publicly accessible information but are available on reasonable request.

\section{Authors' contributions}

NAM, JF, and CX collected information and wrote the manuscript. SZG collected information and edited the manuscript. All authors read and approved the final version of this manuscript.

\section{Ethics approval and consent to participate}

Not applicable. 


\section{Patient consent for publication}

Not applicable.

\section{Competing interests}

The authors declare that they have no competing interests.

\section{References}

1. Shaib Y and El-Serag HB: The epidemiology of cholangiocarcinoma. Semin Liver Dis 24: 115-125, 2004.

2. Patel $\mathrm{N}$ and Benipal B: Incidence of Cholangiocarcinoma in the USA from 2001 to 2015: A US Cancer Statistics Analysis of 50 States. Cureus 11: e3962, 2019.

3. Yao KJ, Jabbour S, Parekh N, Lin Y and Moss RA: Increasing mortality in the United States from cholangiocarcinoma: An analysis of the National Center for Health Statistics Database. BMC Gastroenterol 16: 117, 2016.

4. Mavros MN, Economopoulos KP, Alexiou VG and Pawlik TM: Treatment and Prognosis for Patients With Intrahepatic Cholangiocarcinoma: Systematic Review and Meta-analysis. JAMA Surg 149: 565-574, 2014.

5. Arrington AK, Nelson RA, Falor A, Luu C, Wiatrek RL, Fakih M, Singh $\mathrm{G}$ and Kim J: Impact of medical and surgical intervention on survival in patients with cholangiocarcinoma. World J Gastrointest Surg 5: 178-186, 2013.

6. Valle J, Wasan H, Palmer DH, Cunningham D, Anthoney A, Maraveyas A, Madhusudan S, Iveson T, Hughes S, Pereira SP, et al; ABC-02 Trial Investigators: Cisplatin plus gemcitabine versus gemcitabine for biliary tract cancer. N Engl J Med 362: 1273-1281, 2010.

7. Park JO, Oh DY, Hsu C, Chen JS, Chen LT, Orlando M, Kim JS and Lim HY: Gemcitabine Plus Cisplatin for Advanced Biliary Tract Cancer: A Systematic Review. Cancer Res Treat 47: 343-361, 2015.

8. Javle M,Lowery M, Shroff RT, Weiss KH, Springfeld C, Borad MJ, Ramanathan RK, Goyal L, Sadeghi S, Macarulla T, et al: Phase II Study of BGJ398 in Patients With FGFR-Altered Advanced Cholangiocarcinoma. J Clin Oncol 36: 276-282, 2018.

9. Lowery MA, Burris HA III, Janku F, Shroff RT, Cleary JM, Azad NS, Goyal L, Maher EA, Gore L, Hollebecque A, et al: Safety and activity of ivosidenib in patients with IDH1-mutant advanced cholangiocarcinoma: A phase 1 study. Lancet Gastroenterol Hepatol 4: 711-720, 2019.

10. Akinleye A and Rasool Z: Immune checkpoint inhibitors of PD-L1 as cancer therapeutics. J Hematol Oncol 12: 92, 2019.

11. El-Khoueiry AB, Sangro B, Yau T, Crocenzi TS, Kudo M, Hsu C, Kim TY, Choo SP, Trojan J, Welling TH III, et al: Nivolumab in patients with advanced hepatocellular carcinoma (CheckMate 040): An open-label, non-comparative, phase 1/2 dose escalation and expansion trial. Lancet 389: 2492-2502, 2017.

12. Zhu AX, Finn RS, Edeline J, Cattan S, Ogasawara S, Palmer D Verslype C,Zagonel V, Fartoux L, Vogel A, et al; KEYNOTE-224 investigators: Pembrolizumab in patients with advanced hepatocellular carcinoma previously treated with sorafenib (KEYNOTE-224): A non-randomised, open-label phase 2 trial. Lancet Oncol 19: 940-952, 2018.

13. Gou M, Zhang Y, Si H and Dai G: Efficacy and safety of nivolumab for metastatic biliary tract cancer. OncoTargets Ther 12: 861-867, 2019.

14. Ueno M, Chung HC, Nagrial A, Marabelle A, Kelley RK, Xu L, Mahoney J, Pruitt SK and Oh D: Pembrolizumab for advanced biliary adenocarcinoma: Results from the multicohort, phase 2 KEYNOTE-158 study. Ann Oncol 29 (Suppl 8): viii205-viii270, 2018.

15. Xie C, Duffy AG, Mabry-Hrones D, Wood B, Levy E, Krishnasamy V, Khan J, Wei JS, Agdashian D, Tyagi M, et al: Tremelimumab in Combination With Microwave Ablation in Patients With Refractory Biliary Tract Cancer. Hepatology 69: 2048-2060, 2019.

16. Bonnet D and Dick JE: Human acute myeloid leukemia is organized as a hierarchy that originates from a primitive hematopoietic cell. Nat Med 3: 730-737, 1997.

17. Lapidot T, Sirard C, Vormoor J, Murdoch B, Hoang T, Caceres-Cortes J, Minden M, Paterson B, Caligiuri MA and Dick JE: A cell initiating human acute myeloid leukaemia after transplantation into SCID mice. Nature 367: 645-648, 1994.
18. Yamashita T and Wang XW: Cancer stem cells in the development of liver cancer. J Clin Invest 123: 1911-1918, 2013.

19. Clara JA, Monge C, Yang Y and Takebe N: Targeting signalling pathways and the immune microenvironment of cancer stem cells - a clinical update. Nat Rev Clin Oncol 17: 204-232, 2020.

20. Lytle NK, Barber AG and Reya T: Stem cell fate in cancer growth, progression and therapy resistance. Nat Rev Cancer 18: 669-680, 2018

21. Silver DJ, Sinyuk M, Vogelbaum MA, Ahluwalia MS and Lathia JD: The intersection of cancer, cancer stem cells, and the immune system: Therapeutic opportunities. Neuro-oncol 18 153-159, 2016.

22. Lu W and Kang Y: Epithelial-Mesenchymal Plasticity in Cancer Progression and Metastasis. Dev Cell 49: 361-374, 2019.

23. Lugli A, Iezzi G, Hostettler I, Muraro MG, Mele V, Tornillo L, Carafa V, Spagnoli G, Terracciano L and Zlobec I: Prognostic impact of the expression of putative cancer stem cell markers CD133, CD166, CD44s, EpCAM, and ALDH1 in colorectal cancer. Br J Cancer 103: 382-390, 2010.

24. Cardinale V, Renzi A, Carpino G, Torrice A, Bragazzi MC, Giuliante F, DeRose AM, Fraveto A, Onori P, Napoletano C, et al: Profiles of cancer stem cell subpopulations in cholangiocarcinomas. Am J Pathol 185: 1724-1739, 2015.

25. Singh SK, Clarke ID, Hide T and Dirks PB: Cancer stem cells in nervous system tumors. Oncogene 23: 7267-7273, 2004.

26. Glumac PM and LeBeau AM: The role of CD133 in cancer: A concise review. Clin Transl Med 7: 18, 2018.

27. Bhuria V, Xing J, Scholta T, Bui KC, Nguyen MLT, Malek NP, Bozko P and Plentz RR: Hypoxia induced Sonic Hedgehog signaling regulates cancer stemness, epithelial-to-mesenchymal transition and invasion in cholangiocarcinoma. Exp Cell Res 385: $111671,2019$.

28. Li J, Chen JN, Zeng TT, He F, Chen SP, Ma S, Bi J, Zhu XF and Guan XY: CD133+ liver cancer stem cells resist interferon-gamma-induced autophagy. BMC Cancer 16: 15, 2016.

29. Shimada M, Sugimoto K, Iwahashi S, Utsunomiya T, Morine Y, Imura $\mathrm{S}$ and Ikemoto T: CD133 expression is a potential prognostic indicator in intrahepatic cholangiocarcinoma. J Gastroenterol 45: 896-902, 2010

30. Mima K, Okabe H, Ishimoto T, Hayashi H, Nakagawa $\mathrm{S}$, Kuroki H, Watanabe M, Beppu T, Tamada M, Nagano O, et al: CD44s regulates the TGF- $\beta$-mediated mesenchymal phenotype and is associated with poor prognosis in patients with hepatocellular carcinoma. Cancer Res 72: 3414-3423, 2012.

31. Ishimoto $T$, Nagano $O$, Yae $T$, Tamada M, Motohara $T$, Oshima H, Oshima M, Ikeda T, Asaba R, Yagi H, et al: CD44 variant regulates redox status in cancer cells by stabilizing the $\mathrm{xCT}$ subunit of system $\mathrm{xc}(-)$ and thereby promotes tumor growth. Cancer Cell 19: 387-400, 2011.

32. Suwannakul N, Ma N, Thanan R, Pinlaor S, Ungarreevittaya $P$, Midorikawa K, Hiraku Y, Oikawa S, Kawanishi S and Murata M: Overexpression of CD44 Variant 9: A Novel Cancer Stem Cell Marker in Human Cholangiocarcinoma in Relation to Inflammation. Mediators Inflamm 2018: 4867234, 2018

33. Morrin M and Delaney PV: CD44v6 is not relevant in colorectal tumour progression. Int J Colorectal Dis 17: 30-36, 2002.

34. Coppola D, Hyacinthe M, Fu L, Cantor AB, Karl R, Marcet J, Cooper DL, Nicosia SV and Cooper HS: CD44V6 expression in human colorectal carcinoma. Hum Pathol 29: 627-635, 1998.

35. Mani SA, Guo W, Liao MJ, Eaton EN, Ayyanan A, Zhou AY, Brooks M, Reinhard F, Zhang CC, Shipitsin M, et al: The epithelial-mesenchymal transition generates cells with properties of stem cells. Cell 133: 704-715, 2008.

36. Vaquero J, Lobe C, Tahraoui S, Clapéron A, Mergey M, Merabtene F, Wendum D, Coulouarn C, Housset C, Desbois-Mouthon C, et al: The IGF2/IR/IGF1R Pathway in Tumor Cells and Myofibroblasts Mediates Resistance to EGFR Inhibition in Cholangiocarcinoma. Clin Cancer Res 24: 4282-4296, 2018

37. Diehn M, Cho RW, Lobo NA, Kalisky T, Dorie MJ, Kulp AN, Qian D, Lam JS, Ailles LE, Wong M, et al: Association of reactive oxygen species levels and radioresistance in cancer stem cells. Nature 458: 780-783, 2009.

38. Agrawal S, Kuvshinoff BW, Khoury T, Yu J, Javle MM, LeVea C, Groth J, Coignet LJ and Gibbs JF: CD24 expression is an independent prognostic marker in cholangiocarcinoma. J Gastrointest Surg 11: 445-451, 2007.

39. Zhou FQ, Qi YM, Xu H, Wang QY, Gao XS and Guo HG: Expression of EpCAM and $\mathrm{Wnt} / \beta$-catenin in human colon cancer. Genet Mol Res 14: 4485-4494, 2015. 
40. Yamashita T, Budhu A, Forgues M and Wang XW: Activation of hepatic stem cell marker EpCAM by Wnt-beta-catenin signaling in hepatocellular carcinoma. Cancer Res 67: 10831-10839, 2007.

41. Sulpice L, Rayar M, Turlin B, Boucher E, Bellaud P, Desille M, Meunier B, Clément B, Boudjema K and Coulouarn C: Epithelial cell adhesion molecule is a prognosis marker for intrahepatic cholangiocarcinoma. J Surg Res 192: 117-123, 2014.

42. Vasanthakumar S, Sasikala P, Padma M, Balachandar V, Venkatesh B and Ganesan S: EpCAM as a novel therapeutic target for hepatocellular carcinoma. J Oncological Sci 3: 71-76, 2017.

43. Breuhahn K, Baeuerle PA, Peters M, Prang N, Töx U, Köhne-Volland R, Dries V, Schirmacher P and Leo E: Expression of epithelial cellular adhesion molecule (Ep-CAM) in chronic (necro-)inflammatory liver diseases and hepatocellular carcinoma. Hepatol Res 34: 50-56, 2006.

44. Sun YF, Xu Y, Yang XR, Guo W, Zhang X, Qiu SJ, Shi RY, $\mathrm{Hu} \mathrm{B}$, Zhou J and Fan J: Circulating stem cell-like epithelial cell adhesion molecule-positive tumor cells indicate poor prognosis of hepatocellular carcinoma after curative resection. Hepatology 57: 1458-1468, 2013.

45. Wang M, Xiao J, Shen M, Yahong Y, Tian R, Zhu F, Jiang J, Du Z, $\mathrm{Hu} \mathrm{J}$, Liu W, et al: Isolation and characterization of tumorigenic extrahepatic cholangiocarcinoma cells with stem cell-like properties. Int J Cancer 128: 72-81, 2011.

46. Shuang ZY, Wu WC, Xu J, Lin G, Liu YC, Lao XM, Zheng L and $\mathrm{Li}$ S: Transforming growth factor- $\beta 1$-induced epithelial-mesenchymal transition generates ALDH-positive cells with stem cell properties in cholangiocarcinoma. Cancer Lett 354: 320-328, 2014.

47. Lingala S, Cui YY, Chen X, Ruebner BH, Qian XF, Zern MA and Wu J: Immunohistochemical staining of cancer stem cell markers in hepatocellular carcinoma. Exp Mol Pathol 89: 27-35, 2010.

48. You L, Guo X and Huang Y: Correlation of Cancer Stem-Cell Markers OCT4, SOX2, and NANOG with Clinicopathological Features and Prognosis in Operative Patients with Rectal Cancer. Yonsei Med J 59: 35-42, 2018.

49. Zhang MX, Gan W, Jing CY, Zheng SS, Yi Y, Zhang J, Xu X, Lin JJ, Zhang BH and Qiu SJ: High expression of Oct4 and Nanog predict poor prognosis in intrahepatic cholangiocarcinoma patients after curative resection. J Cancer 10: 1313-1324, 2019.

50. Gu MJ and Jang BI: Clinicopathologic significance of Sox2, CD44 and CD44v6 expression in intrahepatic cholangiocarcinoma. Pathol Oncol Res 20: 655-660, 2014

51. Visvader JE and Lindeman GJ: Cancer stem cells in solid tumours: Accumulating evidence and unresolved questions. Nat Rev Cancer 8: 755-768, 2008.

52. Elaimy AL and Mercurio AM: Convergence of VEGF and YAP/TAZ signaling: Implications for angiogenesis and cancer biology. Sci Signal 11: eaau1165, 2018.

53. Guo L and Teng L: YAP/TAZ for cancer therapy: Opportunities and challenges (Review). Int J Oncol 46: 1444-1452, 2015.

54. Sugihara T, Isomoto $\mathrm{H}$, Gores $\mathrm{G}$ and Smoot R: YAP and the Hippo pathway in cholangiocarcinoma. J Gastroenterol 54: 485-491, 2019.

55. Kim MK, Jang JW and Bae SC: DNA binding partners of YAP/TAZ. BMB Rep 51: 126-133, 2018.

56. Kim HM, Jung WH and Koo JS: Expression of Yes-associated protein (YAP) in metastatic breast cancer. Int J Clin Exp Pathol 8 : 11248-11257, 2015.

57. Sugiura K, Mishima T, Takano S, Yoshitomi H, Furukawa K Takayashiki T, Kuboki S, Takada M, Miyazaki M and Ohtsuka M: The Expression of Yes-Associated Protein (YAP) Maintains Putative Cancer Stemness and Is Associated with Poor Prognosis in Intrahepatic Cholangiocarcinoma. Am J Pathol 189: 1863-1877, 2019.

58. Xu MZ, Yao TJ, Lee NP, Ng IO, Chan YT, Zender L, Lowe SW, Poon RT and Luk JM: Yes-associated protein is an independent prognostic marker in hepatocellular carcinoma. Cancer 115 4576-4585, 2009.

59. Lee K, Lee KB, Jung HY, Yi NJ, Lee KW, Suh KS and Jang JJ: The correlation between poor prognosis and increased yes-associated protein 1 expression in keratin 19 expressing hepatocellular carcinomas and cholangiocarcinomas. BMC Cancer 17: 441, 2017.

60. Liu JY, Li YH, Lin HX, Liao YJ, Mai SJ, Liu ZW, Zhang ZL, Jiang LJ, Zhang JX, Kung HF, et al: Overexpression of YAP 1 contributes to progressive features and poor prognosis of human urothelial carcinoma of the bladder. BMC Cancer 13: 349, 2013
61. Nishio M, Sugimachi K, Goto H, Wang J, Morikawa T, Miyachi Y, Takano Y, Hikasa H, Itoh T, Suzuki SO, et al: Dysregulated YAP1/TAZ and TGF- $\beta$ signaling mediate hepatocarcinogenesis in Mob1a/1b-deficient mice. Proc Natl Acad Sci USA 113 E71-E80, 2016.

62. Song H, Mak KK, Topol L, Yun K, Hu J, Garrett L, Chen Y, Park O, Chang J, Simpson RM, et al: Mammalian Mst1 and Mst2 kinases play essential roles in organ size control and tumor suppression. Proc Natl Acad Sci USA 107: 1431-1436, 2010.

63. Yamada D, Rizvi S, Razumilava N, Bronk SF, Davila JI, Champion MD, Borad MJ, Bezerra JA, Chen X and Gores GJ: IL-33 facilitates oncogene-induced cholangiocarcinoma in mice by an interleukin-6-sensitive mechanism. Hepatology 61: $1627-1642,2015$

64. Song S, Xie M, Scott AW, Jin J, Ma L, Dong X, Skinner HD, Johnson RL, Ding S and Ajani JA: A Novel YAP1 Inhibitor Targets CSC-Enriched Radiation-Resistant Cells and Exerts Strong Antitumor Activity in Esophageal Adenocarcinoma. Mol Cancer Ther 17: 443-454, 2018

65. Song S, Ajani JA, Honjo S, Maru DM, Chen Q, Scott AW, Heallen TR, Xiao L, Hofstetter WL, Weston B, et al: Hippo coactivator YAP1 upregulates SOX9 and endows esophageal cancer cells with stem-like properties. Cancer Res 74: 4170-4182, 2014.

66. Ooki A, Del Carmen Rodriguez Pena M, Marchionni L, Dinalankara W, Begum A, Hahn NM, VandenBussche CJ, Rasheed ZA, Mao S, Netto GJ, et al: YAP1 and COX2 Coordinately Regulate Urothelial Cancer Stem-like Cells. Cancer Res 78: 168-181, 2018

67. Bora-Singhal N, Nguyen J, Schaal C, Perumal D, Singh S, Coppola D and Chellappan S: YAP1 Regulates OCT4 Activity and SOX2 Expression to Facilitate Self-Renewal and Vascular Mimicry of Stem-Like Cells. Stem Cells 33: 1705-1718, 2015.

68. Zhu P, Wang Y, Wu J, Huang G, Liu B, Ye B, Du Y, Gao G, Tian Y, He L, et al: LncBRM initiates YAP1 signalling activation to drive self-renewal of liver cancer stem cells. Nat Commun 7: 13608,2016

69. Li F, Xu Y, Liu B, Singh PK, Zhao W, Jin J, Han G, Scott AW, Dong X, Huo L, et al: YAP1-Mediated CDK6 Activation Confers Radiation Resistance in Esophageal Cancer - Rationale for the Combination of YAP1 and CDK4/6 Inhibitors in Esophageal Cancer. Clin Cancer Res 25: 2264-2277, 2019.

70. Syed IS, Pedram A and Farhat WA: Role of Sonic Hedgehog (Shh) Signaling in Bladder Cancer Stemness and Tumorigenesis. Curr Urol Rep 17: 11, 2016.

71. U.S. National Library of Medicine: A Study Evaluating IPI-926 in Combination With Gemcitabine in Patients With Metastatic Pancreatic Cancer. ClinicalTrials.gov Identifier: NCT01130142. https://clinicaltrials.gov/ct2/show/NCT01130142. Accessed May 25, 2010.

72. Ko AH, LoConte N, Tempero MA, Walker EJ, Kate Kelley R, Lewis S, Chang WC, Kantoff E, Vannier MW, Catenacci DV, et al: A Phase I Study of FOLFIRINOX Plus IPI-926, a Hedgehog Pathway Inhibitor, for Advanced Pancreatic Adenocarcinoma. Pancreas 45: 370-375, 2016

73. Xie H, Paradise BD, Ma WW and Fernandez-Zapico ME: Recent Advances in the Clinical Targeting of Hedgehog/GLI Signaling in Cancer. Cells 8: E394, 2019.

74. Ranganathan P, Weaver KL and Capobianco AJ: Notch signalling in solid tumours: A little bit of everything but not all the time. Nat Rev Cancer 11: 338-351, 2011.

75. Wang Z, Li Y, Banerjee S and Sarkar FH: Emerging role of Notch in stem cells and cancer. Cancer Lett 279: 8-12, 2009.

76. Cigliano A, Wang J, Chen X and Calvisi DF: Role of the Notch signaling in cholangiocarcinoma. Expert Opin Ther Targets 21: 471-483, 2017.

77. Fan B, Malato Y, Calvisi DF, Naqvi S, Razumilava N, Ribback S, Gores GJ, Dombrowski F, Evert M, Chen X, et al: Cholangiocarcinomas can originate from hepatocytes in mice. J Clin Invest 122: 2911-2915, 2012.

78. Wang R, Sun Q, Wang P, Liu M, Xiong S, Luo J, Huang H, Du Q, Geller DA and Cheng B: Notch and Wnt $/ \beta$-catenin signaling pathway play important roles in activating liver cancer stem cells. Oncotarget 7: 5754-5768, 2016.

79. Schatoff EM, Leach BI and Dow LE: Wnt Signaling and Colorectal Cancer. Curr Colorectal Cancer Rep 13: 101-110, 2017.

80. Boulter L, Guest RV, Kendall TJ, Wilson DH, Wojtacha D, Robson AJ, Ridgway RA, Samuel K, Van Rooijen N, Barry ST, et al: WNT signaling drives cholangiocarcinoma growth and can be pharmacologically inhibited. J Clin Invest 125: $1269-1285,2015$ 
81. Park HW, Kim YC, Yu B, Moroishi T, Mo JS, Plouffe SW, Meng Z, Lin KC, Yu FX, Alexander CM, et al: Alternative Wnt Signaling Activates YAP/TAZ. Cell 162: 780-794, 2015.

82. Santoro R, Zanotto M, Simionato F, Zecchetto C, Merz V, Cavallini C, Piro G, Sabbadini F, Boschi F, Scarpa A and Melisi D: Modulating TAK1 expression inhibits YAP and TAZ oncogenic functions in pancreatic cancer. Mol Cancer Ther 19: 247-257, 2020

83. Gray JE, Infante JR, Brail LH, Simon GR, Cooksey JF, Jones SF, Farrington DL, Yeo A, Jackson KA, Chow KH, et al: A first-in-human phase I dose-escalation, pharmacokinetic, and pharmacodynamic evaluation of intravenous LY2090314, a glycogen synthase kinase 3 inhibitor, administered in combination with pemetrexed and carboplatin. Invest New Drugs 33: 1187-1196, 2015.

84. U.S. National Library of Medicine: A Study of BBI503 in Adult Patients With Advanced Hepatobiliary Cancer. ClinicalTrials. gov Identifier: NCT02232633. https://ClinicalTrials. gov/show/NCT02232633. Accessed September 5, 2014

85. Jonker DJ, Laurie SA, Cote GM, Flaherty K, Fuchs CS, Chugh R, Smith DC, Edenfield WJ, Conkling PR, Mier JW, et al: Phase 1 extension study of BBI503, a first-in-class cancer stemness kinase inhibitor, in patients with advanced colorectal cancer. J Clin Oncol 33 (Suppl 15): 3615, 2015.

86. Xiong H, Zhang ZG, Tian XQ, Sun DF, Liang QC, Zhang YJ,Lu R, Chen YX and Fang JY: Inhibition of JAK1, 2/STAT3 signaling induces apoptosis, cell cycle arrest, and reduces tumor cell invasion in colorectal cancer cells. Neoplasia 10: 287-297, 2008

87. U.S. National Library of Medicine: A Study of Napabucasin (BBI-608) in Combination With FOLFIRI in Adult Patients With Previously Treated Metastatic Colorectal Cancer. ClinicalTrials. gov Identifier: NCT02753127. https://clinicaltrials.gov/ct2/show/ NCT02753127. Accessed April 27, 2016.

88. Bendell JC, Hubbard JM, O'Neil BH, Jonker DJ, Starodub A, Peyton JD, Pitot HC, Halfdanarson TR, Nadeau BR, Zubkus JD, et al: Phase 1b/II study of cancer stemness inhibitor napabucasin (BBI-608) in combination with FOLFIRI +/- bevacizumab (bev) in metastatic colorectal cancer (mCRC) patients (pts). J Clin Oncol 35 (Suppl 15): 3529, 2017

89. Beyreis M, Gaisberger M, Jakab M, Neureiter D, Helm K Ritter M, Kiesslich T and Mayr C: The Cancer Stem Cell Inhibitor Napabucasin (BBI608) Shows General Cytotoxicity in Biliary Tract Cancer Cells and Reduces Cancer Stem Cell Characteristics. Cancers (Basel) 11: E276, 2019.

90. Piersma B, Bank RA and Boersema M: Signaling in Fibrosis: TGF- $\beta$, WNT, and YAP/TAZ Converge. Front Med (Lausanne) 2 59, 2015.

91. Kim W, Khan SK and Yang Y: Interacting network of Hippo, Wnt $/ \beta$-catenin and Notch signaling represses liver tumor formation. BMB Rep 50: 1-2, 2017.

92. Rabadán MA, Cayuso J, Le Dréau G, Cruz C, Barzi M, Pons S, Briscoe J and Martí E: Jagged 2 controls the generation of motor neuron and oligodendrocyte progenitors in the ventral spinal cord. Cell Death Differ 19: 209-219, 2012.

93. He J, Sheng T, Stelter AA, Li C, Zhang X, Sinha M, Luxon BA and Xie J: Suppressing Wnt signaling by the hedgehog pathway through sFRP-1. J Biol Chem 281: 35598-35602, 2006.

94. Beier D, Hau P, Proescholdt M, Lohmeier A, Wischhusen J, Oefner PJ, Aigner L, Brawanski A, Bogdahn U and Beier CP: CD133(+) and CD133(-) glioblastoma-derived cancer stem cells show differential growth characteristics and molecular profiles. Cancer Res 67: 4010-4015, 2007.

95. Croker AK, Goodale D, Chu J, Postenka C, Hedley BD, Hess DA and Allan AL: High aldehyde dehydrogenase and expression of cancer stem cell markers selects for breast cancer cells with enhanced malignant and metastatic ability. J Cell Mol Med 13: 2236-2252, 2009.

96. Shmelkov SV, Butler JM, Hooper AT, Hormigo A, Kushner J, Milde T, St Clair R, Baljevic M, White I, Jin DK, et al: CD133 expression is not restricted to stem cells, and both CD133+ and CD133- metastatic colon cancer cells initiate tumors. J Clin Invest 118: 2111-2120, 2008.

97. Schmelzer E, Zhang L, Bruce A, Wauthier E, Ludlow J, Yao HL, Moss N, Melhem A, McClelland R, Turner W, et al: Human hepatic stem cells from fetal and postnatal donors. J Exp Med 204: 1973-1987, 2007

98. Sagrinati C, Netti GS, Mazzinghi B, Lazzeri E, Liotta F, Frosali F, Ronconi E, Meini C, Gacci M, Squecco R, et al: Isolation and characterization of multipotent progenitor cells from the Bowman's capsule of adult human kidneys. J Am Soc Nephrol 17: 2443-2456, 2006.
99. Ma S, Chan KW, Lee TK, Tang KH, Wo JY, Zheng BJ and Guan XY: Aldehyde dehydrogenase discriminates the CD133 liver cancer stem cell populations. Mol Cancer Res 6: 1146-1153, 2008

100. Eramo A, Lotti F, Sette G, Pilozzi E, Biffoni M, Di Virgilio A, Conticello C, Ruco L, Peschle C and De Maria R: Identification and expansion of the tumorigenic lung cancer stem cell population. Cell Death Differ 15: 504-514, 2008.

101.Jaksch M, Múnera J, Bajpai R, Terskikh A and Oshima RG: Cell cycle-dependent variation of a CD133 epitope in human embryonic stem cell, colon cancer, and melanoma cell lines. Cancer Res 68: 7882-7886, 2008.

102. Kryczek I, Liu S, Roh M, Vatan L, Szeliga W, Wei S, Banerjee M, Mao Y, Kotarski J, Wicha MS, et al: Expression of aldehyde dehydrogenase and CD133 defines ovarian cancer stem cells. Int J Cancer 130: 29-39, 2012

103. Silva IA, Bai S, McLean K, Yang K, Griffith K, Thomas D, Ginestier C, Johnston C, Kueck A, Reynolds RK, et al: Aldehyde dehydrogenase in combination with CD133 defines angiogenic ovarian cancer stem cells that portend poor patient survival. Cancer Res 71: 3991-4001, 2011

104. Lardon J, Corbeil D, Huttner WB, Ling Z and Bouwens L: Stem cell marker prominin-1/AC133 is expressed in duct cells of the adult human pancreas. Pancreas 36: e1-e6, 2008

105. Collins AT, Berry PA, Hyde C, Stower MJ and Maitland NJ: Prospective identification of tumorigenic prostate cancer stem cells. Cancer Res 65: 10946-10951, 2005.

106. Singh SK, Hawkins C, Clarke ID, Squire JA, Bayani J, Hide T, Henkelman RM, Cusimano MD and Dirks PB: Identification of human brain tumour initiating cells. Nature 432: 396-401, 2004.

107. O'Brien CA, Pollett A, Gallinger S and Dick JE: A human colon cancer cell capable of initiating tumour growth in immunodeficient mice. Nature 445: 106-110, 2007.

108. Zhou J, Wang H, Cannon V, Wolcott KM, Song H and Yates C: Side population rather than CD133(+) cells distinguishes enriched tumorigenicity in hTERT-immortalized primary prostate cancer cells. Mol Cancer 10: 112, 2011.

109. Avril T, Etcheverry A, Pineau R, Obacz J, Jegou G, Jouan F, Le Reste PJ, Hatami M, Colen RR, Carlson BL, et al: CD90 expression controls migration and predicts dasatinib response in glioblastoma. Clin Cancer Res 23: 7360-7374, 2017.

110. Yamashita T, Honda M, Nakamoto Y, Baba M, Nio K, Hara Y, Zeng SS, Hayashi T, Kondo M, Takatori H, et al: Discrete nature of EpCAM+ and CD90+ cancer stem cells in human hepatocellular carcinoma. Hepatology 57: 1484-1497, 2013.

111. Wang P, Gao Q, Suo Z, Munthe E, Solberg S, Ma L, Wang M, Westerdaal NA, Kvalheim G and Gaudernack G: Identification and characterization of cells with cancer stem cell properties in human primary lung cancer cell lines. PLoS One 8: e57020, 2013.

112. Chen WC, Hsu HP, Li CY, Yang YJ, Hung YH, Cho CY, Wang CY, Weng TY and Lai MD: Cancer stem cell marker CD90 inhibits ovarian cancer formation via $\beta 3$ integrin. Int J Oncol 49: 1881-1889, 2016

113. Jiang J, Zhang Y, Chuai S, Wang Z, Zheng D, Xu F, Zhang Y, Li C, Liang Y and Chen Z: Trastuzumab (herceptin) targets gastric cancer stem cells characterized by CD90 phenotype. Oncogene 31: 671-682, 2012.

114. Flahaut M, Jauquier N, Chevalier N, Nardou K, Balmas Bourloud K, Joseph JM, Barras D, Widmann C, Gross N, Renella $\mathrm{R}$, et al: Aldehyde dehydrogenase activity plays a Key role in the aggressive phenotype of neuroblastoma. BMC Cancer 16: 781, 2016.

115. Ricardo S, Vieira AF, Gerhard R, Leitão D, Pinto R, CameselleTeijeiro JF, Milanezi F, Schmitt F and Paredes J: Breast cancer stem cell markers CD44, CD24 and ALDH1: expression distribution within intrinsic molecular subtype. J Clin Pathol 11: 937-946, 2011

116. Feng H, Liu Y, Bian X, Zhou F and Liu Y: ALDH1A3 affects colon cancer in vitro proliferation and invasion depending on CXCR4 status. Br J Cancer 118: 224-232, 2018.

117. Khorrami S, Zavaran Hosseini A, Mowla SJ and Malekzadeh R: Verification of ALDH Activity as a Biomarker in Colon Cancer Stem Cells-Derived HT-29 Cell Line. Iran J Cancer Prev 8: e3446, 2015 .

118. Moreb JS, Baker HV, Chang LJ, Amaya M, Lopez MC, Ostmark B and Chou W: ALDH isozymes downregulation affects cell growth, cell motility and gene expression in lung cancer cells. Mol Cancer 7: 87, 2008. 
119. Yan J, De Melo J, Cutz JC, Aziz T and Tang D: Aldehyde dehydrogenase $3 \mathrm{~A} 1$ associates with prostate tumorigenesis. $\mathrm{Br}$ J Cancer 110: 2593-2603, 2014.

120. Li W, Ma H,Zhang J, Zhu L, Wang C and Yang Y: Unraveling the roles of CD44/CD24 and ALDH1 as cancer stem cell markers in tumorigenesis and metastasis. Sci Rep 7: 13856, 2017.

121.Luo Y, Dallaglio K, Chen Y, Robinson WA, Robinson SE, McCarter MD, Wang J, Gonzalez R, Thompson DC, Norris DA, et al: ALDH1A isozymes are markers of human melanoma stem cells and potential therapeutic targets. Stem Cells 30: 2100-2113, 2012.

122. Mueller MT, Hermann PC, Witthauer J, Rubio-Viqueira B, Leicht SF, Huber S, Ellwart JW, Mustafa M, Bartenstein P, D'Haese JG, et al: Combined targeted treatment to eliminate tumorigenic cancer stem cells in human pancreatic cancer. Gastroenterology 137: 1102-1113, 2009.

123. Pietras A, Katz AM, Ekström EJ, Wee B, Halliday JJ, Pitter KL, Werbeck JL, Amankulor NM, Huse JT and Holland EC: Osteopontin-CD44 signaling in the glioma perivascular niche enhances cancer stem cell phenotypes and promotes aggressive tumor growth. Cell Stem Cell 14: 357-369, 2014.

124.Fu J, Yang QY, Sai K, Chen FR, Pang JC, Ng HK, Kwan AL and Chen ZP: TGM2 inhibition attenuates ID1 expression in CD44-high glioma-initiating cells. Neuro-oncol 15: 1353-1365, 2013.

125. Todaro M, Gaggianesi M, Catalano V, Benfante A, Iovino F, Biffoni M, Apuzzo T, Sperduti I, Volpe S, Cocorullo G, et al: $\mathrm{CD} 44 \mathrm{v} 6$ is a marker of constitutive and reprogrammed cancer stem cells driving colon cancer metastasis. Cell Stem Cell 14: 342-356, 2014.

126. Paradis V, Ferlicot S, Ghannam E, Zeimoura L, Blanchet P, Eschwége P, Jardin A, Benoît G and Bedossa P: CD44 is an independent prognostic factor in conventional renal cell carcinomas. J Urol 161: 1984-1987, 1999.

127.Zhu Z, Hao X, Yan M, Yao M, Ge C, Gu J and Li J: Cancer stem/progenitor cells are highly enriched in CD133+CD44+ population in hepatocellular carcinoma. Int J Cancer 126: 2067-2078, 2010.

128.He QZ, Luo XZ, Wang K, Zhou Q, Ao H, Yang Y, Li SX, Li Y, Zhu HT and Duan T: Isolation and characterization of cancer stem cells from high-grade serous ovarian carcinomas. Cell Physiol Biochem 33: 173-184, 2014.

129. Patrawala L, Calhoun T, Schneider-Broussard R, Li H, Bhatia B, Tang S, Reilly JG, Chandra D, Zhou J, Claypool K, et al: Highly purified CD44+ prostate cancer cells from xenograft human tumors are enriched in tumorigenic and metastatic progenitor cells. Oncogene 25: 1696-1708, 2006.

130. Wakamatsu Y, Sakamoto N, Oo HZ, Naito Y, Uraoka N, Anami K, Sentani K, Oue N and Yasui W: Expression of cancer stem cell markers ALDH1, CD44 and CD133 in primary tumor and lymph node metastasis of gastric cancer. Pathol Int62: $112-119,2012$

131. Kimura Y, Goi T, Nakazawa T, Hirono Y, Katayama K, Urano T and Yamaguchi A: CD44variant exon 9 plays an important role in colon cancer initiating cells. Oncotarget 4: 785-791, 2013.

132. Yae T, Tsuchihashi K, Ishimoto T, Motohara T, Yoshikawa M, Yoshida GJ, Wada T, Masuko T, Mogushi K, Tanaka H, et al: Alternative splicing of CD44 mRNA by ESRP1 enhances lung colonization of metastatic cancer cell. Nat Commun 3: 883, 2012 .
133. Li C, Heidt DG, Dalerba P, Burant CF, Zhang L, Adsay V, Wicha M, Clarke MF and Simeone DM: Identification of pancreatic cancer stem cells. Cancer Res 67: 1030-1037, 2007.

134. Takaishi S, Okumura T, Tu S, Wang SS, Shibata W, Vigneshwaran R, Gordon SA, Shimada Y and Wang TC: Identification of gastric cancer stem cells using the cell surface marker CD44. Stem Cells 27: 1006-1020, 2009.

135. Wang T, Gantier MP, Xiang D, Bean AG, Bruce M, Zhou SF, Khasraw M, Ward A, Wang L, Wei MQ, et al: EpCAM aptamer-mediated survivin silencing sensitized cancer stem cells to doxorubicin in a breast cancer model. Theranostics 5: 1456,2015

136. Münz M, Kieu C, Mack B, Schmitt B, Zeidler R and Gires O: The carcinoma-associated antigen EpCAM upregulates c-myc and induces cell proliferation. Oncogene 23: 5748, 2004.

137. Yeung TM, Gandhi SC, Wilding JL, Muschel R and Bodmer WF: Cancer stem cells from colorectal cancer-derived cell lines. Proc Natl Acad Sci USA 107: 3722-3727, 2010.

138. Lee TK, Castilho A, Cheung VC, Tang KH, Ma S and Ng IO: CD24(+) liver tumor-initiating cells drive self-renewal and tumor initiation through STAT3-mediated NANOG regulation. Cell Stem Cell 9: 50-63, 2011.

139. Gangemi RM, Griffero F, Marubbi D, Perera M, Capra MC, Malatesta P, Ravetti GL, Zona GL, Daga A and Corte G: SOX2 silencing in glioblastoma tumor-initiating cells causes stop of proliferation and loss of tumorigenicity. Stem Cells 27: 40-48, 2009.

140. Chen Y, Shi L, Zhang L, Li R, Liang J, Yu W, Sun L, Yang X, Wang Y, Zhang Y, et al: The molecular mechanism governing the oncogenic potential of SOX2 in breast cancer. J Biol Chem 283: 17969-17978, 2008.

141. Chou YT, Lee CC, Hsiao SH, Lin SE, Lin SC, Chung CH, Chung $\mathrm{CH}$, Kao YR, Wang YH, Chen CT, et al: The emerging role of SOX2 in cell proliferation and survival and its crosstalk with oncogenic signaling in lung cancer. Stem Cells 31: 2607-2619, 2013.

142. Higgins DM, Wang R, Milligan B, Schroeder M, Carlson B, Pokorny J, Cheshier SH, Meyer FB, Weissman IL, Sarkaria JN, et al: Brain tumor stem cell multipotency correlates with nanog expression and extent of passaging in human glioblastoma xenografts. Oncotarget 4: 792-801, 2013.

143. Jeter CR, Badeaux M, Choy G, Chandra D, Patrawala L, Liu C, Calhoun-Davis T, Zaehres H, Daley GQ and Tang DG: Functional evidence that the self-renewal gene NANOG regulates human tumor development. Stem Cells 27: 993-1005, 2009.

144.Hoei-Hansen CE, Almstrup K, Nielsen JE, Brask Sonne S, Graem N, Skakkebaek NE, Leffers H and Rajpert-De Meyts E: Stem cell pluripotency factor NANOG is expressed in human fetal gonocytes, testicular carcinoma in situ and germ cell tumours. Histopathology 47: 48-56, 2005.

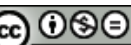

This work is licensed under a Creative Commons Attribution-NonCommercial-NoDerivatives 4.0 International (CC BY-NC-ND 4.0) License. 